\title{
Genocidio: derrotero e historia de un concepto y sus discusiones
}

\section{( Mariano Nagy"}

Fecha de recepción: 28 de octubre de 2018. Fecha de aceptación: 15 de marzo de 2019

Palabras clave

genocidio pueblos indígenas negacionismo

\section{Key words} genocide Indigenous peoples negationism

\section{Resumen}

El crimen que Raphael Lemkin definió como genocidio en 1944 es de larga data. Su inclusión como delito del derecho internacional fue producto de arduas discusiones e intensas acciones de militancia, inescindibles del contexto político en el que se produjeron. Este artículo intenta reponer los sinuosos caminos históricos y sus debates hasta la sanción de la CONUG, los planteos posteriores, los intentos de ampliación y actualización de la Convención y la interrelación entre ciencias sociales y jurídicas en la comprensión del concepto y sus alcances actualmente. Por último, estas cuestiones se retoman en un conjunto de reflexiones referidas al proceso denominado Conquista del Desierto (1879-1885) y las críticas a su caracterización como genocidio. Entre ellas se analizan los deslizamientos hacia el negacionismo; es decir, ciertos enfoques sobre supuestos aspectos del genocidio como: anacronismo, negación de la agencia indígena, característica militante no académica y la Conquista del Desierto como guerra.

\section{Genocide: trajectory and history of a concept and the discussions surrounding it}
Abstract
Raphael Lemkin defined genocide as a crime in 1944, but its inclusion as a crime of international law was the product of arduous discussions and intense acts of unquestionable militancy that cannot be separated from the political context in which they occurred. This article intents to reconstruct the winding historical paths and debates that led to the CONUG sanction, the subsequent proposals, the attempts to extend and update the Convention and the interrelation between social and legal sciences to understand the concept and its current scope. These issues are taken up in a set of reflections about the Conquest of the Desert process (1879-1885) and the criticisms of its characterization as genocide. This paper particularly analyzes the tendency towards denial; that is, approaches taking into consideration aspects of genocide such as: anachronism, denial of indigenous agency, non-academic activism, and the Conquest of the Desert understood as a war.

* Instituto de Ciencias Antropológicas, Facultad de Filosofía y Letras, Universidad de Buenos Aires. Consejo Nacional de Investigaciones Científicas y Técnicas (CONICET). Ciudad Autónoma de Buenos Aires, Argentina. Email: nagy. mariano@gmail.com 


\section{Introducción}

A 70 años del origen de la Convención de la Organización de las Naciones Unidas para la Prevención y Sanción del Delito de Genocidio de 1948 (en adelante, CONUG) puede afirmarse que dicho hito no significó el cierre de los debates en torno a tales crímenes ni tampoco el punto de inicio. Más bien se trató de una tendencia que fue tomando forma a medida que se originaban/ consolidaban los flamantes estados en la era moderna, primero con acuerdos endebles y propuestas de sanciones descartadas o no aplicadas, y luego con un marco normativo que adquirió mayor vigor a partir de la segunda mitad del siglo XIX de la mano de los nacionalismos. Sin embargo, los sucesos de la Segunda Guerra Mundial (1939-1945) y el consenso entre las naciones de condenar los crímenes perpetrados en el conflicto bélico marcaron la agenda de los primeros años de posguerra y fueron decisivos en la tipificación, caracterización y difusión pública de delitos como crímenes de guerra, crímenes de lesa humanidad y genocidio.

En los siguientes apartados se exponen algunos de esos sinuosos pasos o etapas que culminarían en la CONUG de 1948. El repaso posee una perspectiva histórica y no pretende erigirse en una cronología desde la óptica jurídica, aunque en este tópico la simbiosis entre ambas disciplinas es evidente, o al menos manifiesta una relación dialéctica ineludible. No obstante, en el trabajo prevalece una perspectiva diacrónica de diversas fuentes y teorías originadas en los campos jurídico y social respecto al origen y al debate en torno al concepto de genocidio. Entre ellos sobresalen los Genocide Studies y el derecho internacional en clave histórico-política y, en el plano local, los debates que aluden a la Conquista del Desierto y la dictadura militar (1976-1983) como genocidio.

Para tal fin se recuperan y analizan trabajos de autores jurídicos y cientistas sociales, tratados, artículos periodísticos, códigos de guerra, convenciones, resoluciones, informes y borradores de distintos organismos internacionales.

\section{Antecedentes históricos hasta la Gran Guerra}

La paz de Westfalia de 1648, exactamente tres siglos antes de la CONUG, es señalada como el hito de fundación de un orden internacional secular liderado por estados nacionales. Celebrada mediante una serie de tratados en las ciudades alemanas de Münster y Osnabrück puso fin a las guerras de los Ochenta Años (1568-1648), al reconocer la independencia de las Provincias Unidas de los Países Bajos y marcar el fin de la hegemonía de la monarquía hispánica en la región, y de los Treinta Años (1618-1648), en la que participaron distintos estados europeos. Westfalia dejó como legado el primer intento de coordinación internacional de la Europa moderna con acuerdos multilaterales fundamentados en los principios de soberanía, igualdad y equilibrio entre las potencias (Elliott, 1999: 131), el reconocimiento de la igualdad jurídica de las tres grandes confesiones cristianas, el principio de autodeterminación de los pueblos, de cooperación internacional y solución pacífica de los conflictos, la inviolabilidad de las fronteras, la no intervención en los asuntos de otros estados y el respeto por las minorías (Galán Martín, 2015: 42). Con todo, como lo demostrarían los constantes conflictos de los siglos sucesivos, Europa seguiría siendo una civilización militar cuyo estado natural era la guerra (Elliott, 1999: 134). 
1. CICR, 2017. Recuerdo de Solferino (1859) de Henry Dunant en 1862. Disponible en Internet: https:// www.icrc.org/es/publication/ recuerdo-de-solferino. Consultado el: 26 de enero de 2018 .

2. Nombre que se debe a su redactor, Francis Lieber, profesor de Columbia College, Nueva York, Estados Unidos.

3. Código Lieber. Disponible en Internet: https://ihl-databases.icrc. org/ihl//NTRO/110. Consultado el: 26 de enero de 2018.

4. Información extraída de la página electrónica de la Cruz Roja internacional. Disponible en Internet: https://ihl-databases.icrc.org. Consultado el: 14 de mayo de 2017 .

5. Además se estableció la Corte Permanente de Arbitraje para mediar en conflictos entre estados, la que comenzaría a funcionar en 1902. Página electrónica de la Corte Internacional de Justicia. Disponible en Internet: http://www.un.org/ es/icj/hague.shtml. Consultado el: 15 de mayo de 2018
En la segunda mitad del siglo XIX, tal vez por las consecuencias del aumento en la escala y la capacidad de daño a partir de los avances de la segunda fase de la revolución industrial con la que contaban los contendientes, se incrementaron los esfuerzos de las naciones por generar un marco regulatorio internacional en torno a las acciones permitidas y prohibidas en las guerras, incluyendo la protección de la población civil. En efecto, según las propias memorias del Comité Internacional de la Cruz Roja su fundación en 1863 se relaciona con las memorias de la Batalla de Solferino (1859) escritas por Henry Dunant en 1862, ciudadano de Ginebra y testigo presencial del enfrentamiento entre los ejércitos austríaco, francés y piamontés en el marco de la conformación del estado nacional italiano. En ellas da cuenta de las vidas que se podrían haber salvado si los ejércitos hubieran permitido la atención de los lastimados. ${ }^{1}$ Los diez artículos de la Convención de Ginebra de 1864 firmada por dieciséis países apuntan al socorro de los heridos.

En 1863, en el marco de la Guerra de Secesión de los Estados Unidos (18611865), el extenso Código Lieber ${ }^{2}$ de 157 artículos representó el primer intento de codificar las leyes de la guerra y, en tal sentido, fue una fuerte influencia para la Conferencia de la Guerra de Bruselas (1874) y las convenciones internacionales de La Haya (1899 y 1907). Revisado por una junta de oficiales y promulgado por el presidente Abraham Lincoln, advertía de manera explícita acerca del tratamiento que debía brindarse a los prisioneros de guerra:

Un prisionero de guerra está sujeto a no recibir castigos por ser un enemigo público, ni que se le imponga ninguna venganza ni ningún sufrimiento intencional, o desgracia, por encarcelamiento cruel, falta de alimentos, mutilación, muerte o cualquier otra barbaridad (Código Lieber, art. 56). ${ }^{3}$

En 1874, en Bruselas, delegados de quince países europeos revisaron y aprobaron con modificaciones menores la propuesta de Rusia de un acuerdo internacional sobre las leyes y costumbres de la guerra. Sobre esa base, el Instituto de Derecho Internacional fundado en 1873 designó un comité para estudiar la Declaración de Bruselas que en 1880 derivó en la adopción del Manual de Leyes y Costumbres de Guerra de Oxford. Tanto la Declaración de Bruselas de 1874 como el Manual de Oxford de 1880, componen la base de los dos Convenios de La Haya sobre guerra terrestre y los reglamentos anexos a ellos, adoptados en 1899 y 1907.4

Es justamente en la primera conferencia de La Haya, en 1899, donde con la participación de más de 100 delegados de veintiséis países se intentó la regulación jurídica internacional de las leyes y costumbres de la guerra terrestre ${ }^{5}$ y puede rastrearse el antecedente de la aplicación legal de la idea de crimen de lesa humanidad (Vives Chillida, 2003: 340).

Cabe señalar que Diana Lenton (2010: 41) ha publicado una nota del diario La Nación de 1878 cuyo tema es la masacre de 60 ranqueles en Villa Mercedes, provincia de San Luis. El artículo refiere al hecho como un crimen de lesa humanidad. A su vez, William Schabas recupera distintas citas que hacen alusión a crímenes de lesa humanidad, incluso ya en 1789 durante la revolución francesa:

La expresión "crímenes contra la humanidad" parece haber estado en uso durante muchos años. Durante los debates en la Asamblea Nacional, el revolucionario francés Robespierre describió al Rey, Luis XVI, como un "criminal contra la humanidad". En 1890, un observador estadounidense, 
George Washington Williams, escribió al Secretario de Estado de los Estados Unidos que el régimen del rey Leopoldo en el Congo era responsable de "crímenes contra la humanidad". En 1906, Robert Lansing describió la trata de esclavos como un crimen contra la humanidad (Schabas, 2009: 20, la traducción es nuestra).

Específicamente en el campo jurídico, el concepto "leyes de humanidad" fue incorporado en el preámbulo de la Convención de La Haya en 1899 mediante la cláusula Martens, en honor al jurista ruso Fyodorovich Martens. En 1905, la guerra entre Rusia y Japón retrasó la celebración de la segunda Convención de La Haya, finalmente celebrada en 1907 gracias a la tenaz insistencia rusa personificada en el propio Martens. En dicha ocasión participaron diecisiete países latinoamericanos, entre ellos Argentina, ${ }^{6}$ y sus resultados fueron ambivalentes: por un lado, constituyen un legado importante en torno al derecho, las relaciones internacionales y el tratamiento de las poblaciones civiles en los territorios ocupados; por el otro, dichos resultados no fueron ratificados por los estados participantes $\mathrm{y}$, en muchos casos, resultaron ignorados durante ambas guerras mundiales.

Aun así, en mayo de 1915, es decir en pleno desarrollo de la Gran Guerra (1914-1918), una declaración conjunta por parte de los gobiernos de Francia, Gran Bretaña y Rusia sobre las masacres de armenios en el Imperio Otomano afirmó la presencia de estos nuevos crímenes de Turquía contra la humanidad y la civilización. La declaración anunciaba además que todos los miembros del gobierno otomano y sus agentes serían personalmente responsables de dichos crímenes (Schabas, 2009: 20).

Finalizada la Gran Guerra en 1918, se planteó la posibilidad de juzgar a los derrotados por crímenes de guerra y a los líderes turcos por las masacres a la minoría armenia. Por distintos motivos, ambos procesos no tuvieron lugar o se interrumpieron. ${ }^{7}$ En el Tratado de paz de Sevrés (1920), firmado entre el imperio otomano y potencias aliadas se plasmaron los intentos de juzgamientos por crímenes de guerra, de lesa humanidad y por la masacre y deportación de armenios. Turquía en principio lo aceptó pero nunca lo ratificó y negoció un nuevo tratado de paz -de Lausana, 1923- que desembocaría en una amnistía general para todos los crímenes perpetrados entre 1914 y 1922.

Más adeptos parecía sumar la idea de enjuiciar al Kaiser Guillermo II $^{8}$ y a diversos funcionarios alemanes por crímenes de guerra durante la contienda bélica. ${ }^{9}$ En la segunda sesión plenaria de la Conferencia de la Paz, realizada en París en enero de 1919, se creó una Comisión sobre la Responsabilidad de los Autores de la Guerra y la Aplicación de Sanciones. Compuesta por quince representantes de los países victoriosos, la comisión tenía el mandato de investigar e informar sobre las violaciones de las leyes y costumbres de la guerra y de las leyes de la humanidad. Según William Schabas:

[...] algunas de estas violaciones se acercaron al comportamiento criminal ahora definido como genocidio o crímenes de lesa humanidad e involucraron la persecución de minorías o grupos étnicos pero enmarcadas en "intentos de desnacionalizar a los habitantes del territorio ocupado": La Comisión propuso el establecimiento de un "Alto Tribunal" internacional e instó a "que todas las personas enemigas presuntamente culpables de ofensas" contra las leyes y costumbres de la guerra y las leyes de la humanidad" estén excluidas de cualquier amnistía y sean llevados ante los tribunales nacionales o ante el Tribunal Superior (Schabas, 2009: 21-22, la traducción es nuestra).
6. En 1899 México fue el único país latinoamericano en participar. En 1907 la delegación argentina estuvo encabezada por Roque Sáenz Peña, luego presidente de la nación entre 1910 y 1914

7. En el caso del Imperio Otomano, el gobierno británico comunicó a las autoridades turcas que juzgaría a los responsables de la masacre de armenios. Las autoridades turcas en principio aceptaron esperando un resultado más favorable en las negociaciones de paz pero el rechazo creció frente a la posibilidad de que los aliados desmembraran el imperio (Akcam, 2010: 295). No obstante, Gran Bretaña intentó impulsar juicios y trasladó casi 70 detenidos a Malta pero luego terminó negociando su liberación. A comienzos de la década de 1920, la consolidación del estado nacional turco, conformado por antiguos integrantes del movimiento de los “jóvenes turcos”, con Mustafá Kemal a la cabeza, impulsó la suspensión de los juicios y declaró inocentes a los imputados de los crímenes contra la minoría armenia (Artinian y Papazian, 2013: 10).

8. Friedrich Wilhelm Viktor, Guillermo II (1859-1941), “hijo de Federico III de Prusia y la princesa Victoria de Inglaterra, fue proclamado emperador de Alemania en 1888, tras el breve reinado de su padre fallecido ese año. Destituyó al canciller Bismarck en 1890 e inició un plan de reformas internas que lanzaría a Alemania a la industrialización [...] promovió las acciones colonialistas como réplica a la política expansionista del Reino Unido. Gobernó hasta 1918 cuando se exilió a Países Bajos, donde vivió hasta su muerte". Página electrónica Biografías y vidas. Disponible en Internet: https://www.biografiasyvidas.com/ biografia/g/guillermo_ii_alemania. htm. Consultado el: 16 de junio de 2018.

9. El artículo 228 del Tratado de Versalles sostuvo que el Gobierno alemán reconoce a las potencias aliadas y asociadas el derecho de llevar ante sus tribunales militares a los acusados de haber cometido actos contrarios a las leyes y a las costumbres de la guerra. Disponible en Internet: http://constitucionweb.blogspot. com/2012/o2/tratado-de-versalles1919-texto-en.html. Consultado el: 9 de abril de 2018. 
10. Tratado de Versalles, artículo 227. Disponible en Internet: http://constitucionweb.blogspot. com/2012/o2/tratado-de-versalles1919-texto-en.html. Consultado el: 9 de abril de 2018.
A su vez, en la sección VII dedicada a las sanciones, el Tratado de Versalles (1919) estipulaba que el Kaiser Guillermo II iba a ser juzgado, ${ }^{10}$ aunque esto no sucedió porque los Países Bajos se negaron a extraditarlo aduciendo que de hacerlo violarían su neutralidad. A su vez, Alemania propuso -y fue aceptado- que la corte Suprema de Leipzig juzgara a los otros acusados bajo el código militar alemán pero apenas se llevaron adelante un puñado de juicios que realizaron sentencias menores (Gerd, 2014). Así, por un lado, los intentos de juzgar crímenes tras la Gran Guerra fueron fallidos pero, por otro, instalaron la atención sobre el tema de generar mecanismos para el juzgamiento de crímenes internacionales.

\section{El derrotero de entreguerras}

11. Lemkin fue un jurista polaco nacido en 1900 , su familia fue asesinada por el nazismo pero él pudo escapar. Fue quien acuñó el concepto de genocidio. Ver Vrdoljak (2009) y Sands (2017)

12. Lemkin, R. (1933). Actos que constituyen un peligro general (transnacional) considerados como delitos contra la ley de las naciones. Disponible en Internet: http:// www.preventgenocide.org/lemkin/ madrid1933-english.htm\#3. Consultado el: 14 de abril de 2018. (La traducción es nuestra).

13. Lemkin, R. (1933). Actos que constituyen un peligro general (transnacional) considerados como delitos contra la ley de las naciones Disponible en Internet: http:// www.preventgenocide.org/lemkin/ madrid1933-english.htm\#3. Consultado el: 14 de abril de 2018. (La traducción es nuestra).
En la década de 1930, Raphael Lemkin ${ }^{11}$ ya había dado pasos sustanciales en torno a la definición de los crímenes que, una década más tarde, denominaría genocidio.

En 1933 el jurista polaco envió una propuesta a la 5ํㅡㄹ Conferencia sobre Derecho Internacional de Madrid para intentar tipificar dos nuevas figuras penales: los delitos de "barbarie" -destrucción física de individuos debido a la pertenencia a grupos nacionales, religiosos o raciales- y "vandalismo" -los ataques sistemáticos producidos por el estado a la cultura de tales grupos. Lemkin sugería que este tipo de delitos debían internacionalizarse, dado que la peculiar gravedad de los mismos justificaba anular los principios de territorialidad, como modo de que los responsables pudieran ser llevados a juicio en sus propios países, en el país donde se hubiera cometido el delito y/o en cualquier lado en el cual hubieran buscado refugio (Feierstein, 2009: 23)

CONSIDERAMOS los actos de exterminio dirigidos contra las colectividades étnicas, religiosas o sociales sea cual sea el motivo (político, religioso, etc.); por ejemplo masacres, pogromos, acciones emprendidas para arruinar la existencia económica de los miembros de una comunidad, etc. También pertenecen a esta categoría todo tipo de brutalidades que atacan la dignidad del individuo en los casos en que estos actos de humillación tienen su origen en una campaña de exterminio dirigida contra la colectividad en la que la víctima es miembro. Todos los actos de este carácter constituyen una ofensa contra la ley de las naciones que llamaremos "barbarie". ${ }^{12}$

UN ATENTADO QUE SE DIRIGE A UNA COLECTIVIDAD también puede tomar la forma de una destrucción sistemática y organizada del arte y el patrimonio cultural de una colectividad. La contribución de cualquier colectividad particular en los campos de la ciencia, las artes y la literatura a la cultura mundial como un todo, forma la riqueza de toda la humanidad, aun cuando exhibe características únicas. Por lo tanto, su destrucción debe considerarse como actos de vandalismo dirigidos contra la cultura mundial. ${ }^{13}$

En la década siguiente la categoría de vandalismo se transformaría en genocidio cultural que, como se verá, fue central en las discusiones por su inclusión/ exclusión en la CONUG.

Otra influencia importante en el período de entreguerras respecto a la concepción y protección de grupos fueron los Tratados de Protección de Minorías. La disolución de los imperios, como consecuencia de la finalización de la Gran Guerra en 1918, precipitó el surgimiento de nuevos estados, fronteras y 
colectivos que pasaron de ser dominantes a minorías de las flamantes naciones. En ese marco la Sociedad de Naciones intentó proteger minorías anteponiendo ideas de universalidad y humanidad a las de soberanía territorial con la finalidad de que prevalecerían las nociones de no discriminación y respeto por las identidades. Con todo, los Tratados de Protección de minorías no se originaron por principios humanitarios sino "bajo una perspectiva esencialmente política de mantenimiento de la estabilidad de las nuevas fronteras" (Bautista Jiménez, 2008: 8) y su legado es más importante como referencia jurídica y antecedente de la idea de genocidio que por sus logros concretos de protección de grupos.

\section{De la Segunda Guerra Mundial a Nüremberg}

Dos hechos decisivos para la posguerra tuvieron lugar en pleno desarrollo del conflicto bélico: 1) el acuerdo de Saint James difundido en enero de 1942 por los nueve gobiernos en el exilio ${ }^{14}$ que tenían sede en Londres, y 2) la publicación en 1944 del libro de Rafael Lemkin (2009), El dominio del Eje en la Europa ocupada.

La importancia de Saint James radica en la expresión del deseo común de utilizar el derecho penal para castigar a los culpables y responsables de las atrocidades, asesinatos y muertes en los campos de concentración. Sus autores serían perseguidos y juzgados, una idea que se convirtió en uno de los objetivos de la guerra mediante una comisión de crímenes que luego se convertiría en la Comisión de Crímenes de Guerra de Naciones Unidas (Sands, 2017: 149). JanSrámek, primer ministro del gobierno checoslovaco en el exilio, aseveró:

\begin{abstract}
El Gobierno checo expresa la esperanza de que esta declaración -que establece que los crímenes cometidos por Alemania contra las poblaciones civiles no deben considerarse a la par de actos de guerra o crímenes políticos- se convierta en una parte integral de la ideología de todo el mundo civilizado y posibilitará después de la guerra buscar a todo culpable, entregarlo a la justicia, juzgarlo y ejecutar la sentencia pronunciada. ${ }^{15}$
\end{abstract}

El libro de Lemkin no solo dejaría como legado una exhaustiva investigación respecto a las técnicas de ocupación nazis en los territorios ocupados (parte 1) y sus especificidades al aplicarlas en cada país (parte 2) sino además, y por sobre todo, la reconfiguración de sus propuestas de barbarie y vandalismo de 1933 al acuñar el concepto de genocidio:

[...] el genocidio debería comprenderse como un plan coordinado de diferentes acciones cuyo objetivos es la destrucción de las bases esenciales de la vida de grupos de ciudadanos [...] Los objetivos de un plan semejante serían la desintegración de las instituciones políticas y sociales, de la cultura, del lenguaje, de los sentimientos de patriotismo, de la religión y de la existencia económica de grupos nacionales y la destrucción de la seguridad, libertad, salud y dignidad personales e incluso de las vidas de los individuos que pertenecen a dichos grupos. Las acciones se dirigen contra los individuos, no como individuos, sino como miembros del grupo (Lemkin, [1944] 2009: 153).

Conmovido por el aniquilamiento de millones de armenios y por las políticas del nazismo, Lemkin consideraba que:

El plan genocida debía adaptarse a las consideraciones políticas en los diferentes países. No podía implementarse a la fuerza en todos los estados conquistados, y por lo tanto, el plan varía de acuerdo con los sujetos, las
14. Los gobiernos en el exilio eran Bélgica, Checoslovaquia, Grecia, Luxemburgo, Países Bajos, Noruega, Polonia, Yugoslavia y la Francia del General de Gaulle, a los que se sumaron Gran Bretaña, Canadá, Australia, Nueva Zelanda y Sudáfrica, el embajador soviético y el estadounidense de los gobiernos en el exilio.

15. The New York Times, (1942). "Nueve gobiernos para vengar crímenes", 13/1/1942. (La traducción es nuestra). 
16. Lugares de memoria, en términos de Pierre Nora (1984).
17. Su libro había sido reseñado por The Washington Post y luego por The New York Times; en 1945 nuevamente el primero de los periódicos mencionados en un editorial, impulsó el castigo de los nazis citando El dominio del Eje en la Europa ocupada (Sands, 2017: 254 y 258).
18. En la Conferencia de Yalta de febrero de 1945, unos meses antes de que terminara la guerra, I. Stalin, W. Churchill y F. D. Roosevelt acordaron, entre otras cosas, aprobar la idea de juzgar a los criminales nazis. modalidades y el grado de intensidad de cada uno de los países ocupados (Lemkin, [1944] 2009: 156).

Las diversas técnicas de genocidio implicaban accionar en distintas áreas con el fin de destruir instituciones nacionales o étnicas, estructuras culturales, incluidos el idioma, la religión y la psicología de un grupo (Lemkin, 1947). En lo político incluía destruir administraciones locales, patrones de recuerdo, ${ }^{16}$ prohibir nomenclaturas y nombres de los pueblos conquistados; en lo social abolir leyes o costumbres imponiendo las propias; en lo cultural la prohibición del uso del idioma e imposición de la lengua del perpetrador; en lo económico generar una importante transferencia de recursos desde la población local a la opresora y disminuir las condiciones de vida de los conquistados a un nivel mínimo; en lo biológico el despoblamiento, impedir la reproducción social del grupo; en lo físico el traslado de la población a trabajos forzados; en lo religioso alentar el cambio de religión, destrucción de iglesias o persecución de autoridades del clero (Lemkin, [1944] 2009: 157-167).

Según Ana Vrdoljak, El dominio del Eje en la Europa ocupada transmite cómo la discriminación, segregación y eventual eliminación de grupos se implementaba sistemáticamente a través de leyes y decretos. Reformulando términos como "desnacionalización", "asesinato racial" y su anterior término de "barbarie", Lemkin afirmó que el genocidio no era simplemente el acto de asesinato físico de miembros de un grupo sino un proceso de discriminación sistemática, exclusión y destrucción del grupo y sus manifestaciones culturales y religiosas (Vrdoljak, 2009: 1184). Schabas concluye que la definición de Lemkin era estrecha, ya que abordaba los delitos dirigidos contra "grupos nacionales" en lugar de contra "grupos" en general, pero al mismo tiempo era amplia en la medida en que contemplaba no solo el genocidio físico sino también los actos dirigidos a destruir la cultura y el sustento del grupo (Schabas, 2009: 30).

En 1944, las ideas de Lemkin eran conocidas, ${ }^{17}$ especialmente entre juristas dedicados al derecho internacional. Sin embargo, el "Proyecto de Convención para el Establecimiento de un Tribunal de Crímenes de Guerra de las Naciones Unidas", preparado a fines de ese año, se limitó a la comisión de un delito contra las leyes y costumbres de la guerra, eludiendo así examinar los crímenes perpetrados por los nazis en la propia Alemania antes de 1939 (Schabas, 2009) y exigiendo que las atrocidades hayan sido cometidas en conexión con los crímenes de agresión y los crímenes de guerra (Fernández, 2011: 35).

En las discusiones durante la Conferencia de Londres de junio de $1945^{18}$ las potencias aliadas expresaron preocupación por establecer un principio en virtud del derecho internacional por el cual otros, incluidos ellos mismos, podrían ser responsables de "circunstancias lamentables" en sus propios países, donde minorías son tratadas injustamente (Schabas, 2009: 41), por tanto optaron por caracterizar dichos sucesos como una secuencia más de la guerra de agresión. También en dicha conferencia, pero en agosto, se anunció el estatuto del Tribunal Militar Internacional que funcionaría en el Palacio de Justicia de Nüremberg y su composición de cuatro jueces con sus respectivos suplentes, uno de cada nación aliada: Estados Unidos, Unión Soviética, Francia y Gran Bretaña (artículo 2); quienes juzgarían tres tipos de crímenes: a) contra la paz; b) de guerra y c) contra la humanidad. ${ }^{19}$ Internacional de Nüremberg, 1945 Artículo 6. Disponible en Internet: http://www.cruzroja.es/principal/ documents/1750782/1852538/estatuto_del_tribunal_de_nuremberg. pdf/2009ofa2-esbf-447a-aa96612403df2a66. Consultado el: 15 de mayo de 2018.
La referencia a crimen contra la humanidad que aparece en el inciso $\mathrm{C}$ del artículo 6 reemplazó a la noción de agresión y fue introducida por el fiscal Robert Jackson de Estados Unidos en los borradores de la Conferencia de 
Londres, a sugerencia de "un eminente especialista de Derecho internacional" (Vives Chillida, 2003: 344). Dicha eminencia era Hersch Lauterpach ${ }^{20}$ (Sands, 2017: 164).

En octubre de 1945 los cuatro fiscales principales del Tribunal Militar Internacional presentaron las acusaciones contra una veintena de oficiales nazis de alto rango. Un año después se leería la sentencia. En la acusación, por mérito de Lemkin, la delegación de Estados Unidos ${ }^{21}$ incluyó el crimen de genocidio:

genocidio deliberado y sistemático, a saber, el exterminio de grupos raciales y nacionales, contra la población civil de ciertos territorios ocupados para destruir razas particulares y clases de personas, y grupos nacionales, raciales o religiosos, particularmente Judíos, polacos y gitanos (Schabas, 2009: 43, la traducción es nuestra).

El tema y la figura del jurista polaco no pasaron desapercibidos para la prensa internacional:

En la gran acusación formal de los cuatro gobiernos aliados emitida el 18 de octubre se lee "Alemania ha sido culpable de crímenes deliberados y sistemáticos de genocidio: el exterminio de grupos nacionales, religiosos o raciales, incluidos polacos, judíos y otros". Por primera vez, el término "genocidio" aparece en una acusación pública. ¿Qué significa? ¿Cuáles son sus orígenes y cuáles serán las consecuencias de este nuevo principio de la ley? El autor de la misma es Raphael Lemkin, profesor de la Universidad de Duke, EE.UU y explicó que el término "genocidio" es una síntesis de la palabra griega "genos", que significa raza o tribu, y el latín "cidere", que significa matar. ${ }^{22}$

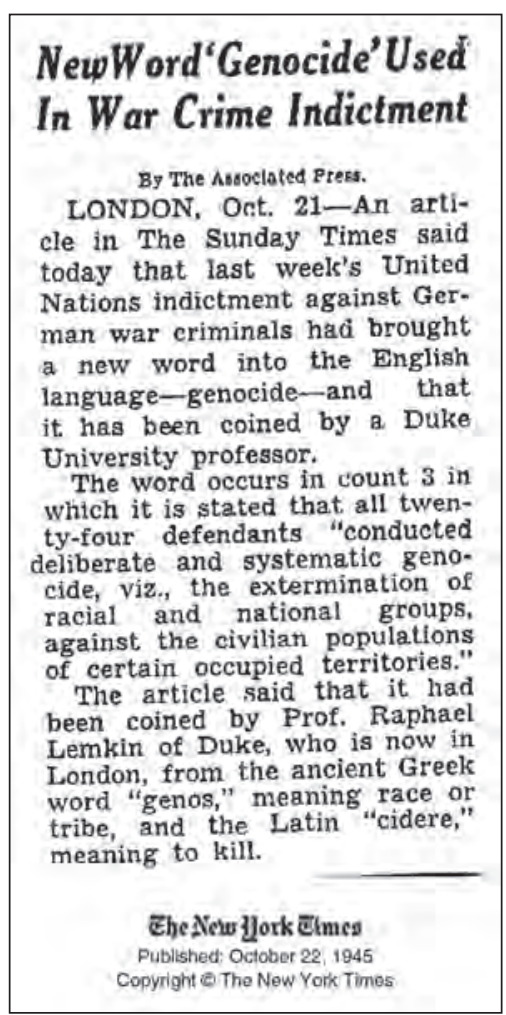

Figura 1. Nueva palabra "genocidio" utilizada en la acusación de crímenes de guerra. The New York Times, 22/10/1945.
20. Hersch Lauterpacht fue un catedrático del derecho internacional nacido en 1897 a quién se le atribuyen, además, otros cambios en los títulos de la acusación de Nüremberg: "Los títulos harían que a la opinión pública le resultara más fácil entender las acciones que se juzgaban, lo que sería útil para recabar apoyos, incrementando la legitimidad de los procesos". En esa línea también propuso titular como crímenes de guerra en lugar del anterior "violaciones a las leyes de la guerra". Las intervenciones de Lauterpacht generaron que fuera invitado por el fiscal británico Hartley Shawcross a redactar la argumentación de su país y a participar en Nüremberg, como parte de la Comisión de Guerra de Gran Bretaña (Vrdoljak, 2009: 1186; Sands, 2017: 164-167).

21. El juez Robert Jackson ya había recurrido al término genocidio en un memorándum durante la Conferencia de Londres de 1945 (Schabas, 2009: 43).

22. Le Monde (1945), "El crimen de genocidio, nuevo principio de derecho internacional", 5/12/1945. Disponible en Internet: http:// www.lemonde.fr/acces-restreint/ archives/article/1945/12/05/002 70 e 49 d 7614 cab 55 ec74466546d 4 6b9_1858194_1819218.html. Consultado el: 19 de junio de 2019. (La traducción es nuestra). 
23. Lemkin le escribió a Maxwell Fyfe transmitiéndole su agradecimiento por el "gran y tan efectivo apoyo" al utilizar el concepto de genocidio en el tribunal (Carta de Lemkin a Fyfe, 26/8/1946, en Vrdoljak, 2009: 1191).

24. El veredicto del Tribunal impuso doce sentencias de muerte, tres cadenas perpetuas, tres absoluciones y otras condenas que oscilaban entre los diez y veinte años de prisión. Página electrónica Encyclopedia. United States Holocaust Memorial Museum. Disponible en Internet: https:// www.ushmm.org/outreach/es/ article.php? Moduleld=10007722. Consultado el: 14 de marzo de 2018.

25. "Bajo la autoridad de dicha ley se celebraron doce juicios adicionales conocidos como 'Subsecuentes Procedimientos de Nüremberg', que fueron celebrados por tribunales militares estadounidenses entre 1946 y 1949. En ellos se enjuiciaron los crímenes cometidos en cada una de las cuatro zonas de la Alemania, una condena in absentia y 35 absoluciones". Página electrónica de la Fundación de la Cátedra Iberoamericana de la Universidad de las Islas Baleares. Disponible en Internet: http://fci. uib.es/Servicios/libros/veracruz/ Fraschina/1.-Los-TribunalesMilitaresInternacionales.cid210831. Consultado el: 14 de marzo de 2018 .

26. En el caso RSHA -La Oficina Central de Seguridad del Reich-, los implicados fueron acusados ante el Tribunal Militar de los Estados con participación en un "programa sistemático de genocidio, destinado a la destrucción de naciones extranjeras y grupos étnicos, en parte por el exterminio asesino, $y$ en parte por la eliminación y supresión de las características nacionales" (Schabas, 2009: 50).

27 En Calle Este-Oeste, Philippe Sands (2017) resalta en tono crítico la conducta insistente de Lemkin en contraposición a un Lauterpacht menos pasional, actitud que Schabas (2009) y Vrdoljak (2009) denominan "lobbying" siguiendo a John Humphrey, el Primer Director de la División de Derechos Humanos de la ONU.

28. Página electrónica de la ONU. Disponible en Internet: https:// undocs.org/es/A/RES/96\%281\%29. Consultado el: 4 de julio de 2018.

29. Borrador de la Organización de Naciones Unidas (ONU). Doc. E/447. 26/6/1947. Disponible en Internet: https://undocs.org/E/447. Consultado el: 21 de julio de 2018 .

30. En su descripción el borrador de la ONU E/447 mencionaba tres tipos de actos de genocidio, físicos, biológicos y culturales, y según Schabas (2009) seguía el enfoque adoptado por el libro de Lemkin. Luego fue suprimido. Disponible en Internet: https://undocs.org/E/794. Consultado el: 22 de julio de 2018.
En junio de 1946, el Fiscal británico David Maxwell Fyfe, al interrogar al funcionario nazi Constantin Von Neurath, le recordó que él había sido acusado de genocidio ${ }^{23}$ categoría a la que los fiscales también recurrieron en sus alegatos:

El genocidio no se restringió al exterminio de los judíos o de los gitanos. Fue aplicado en diferentes formas a Yugoslavia, a los habitantes no alemanes de Alsacia-Lorena, a la gente de Países bajos y de Noruega. Los nazis también usaron varios dispositivos biológicos para lograr el genocidio. Disminuyeron deliberadamente la tasa de natalidad por esterilización, castración y aborto, por separar a los hombres de las mujeres y obstruir matrimonios (Sir Hartley Shawcross, en Schabas, 2009: 44, la traducción es nuestra).

Sin embargo, en la sentencia de octubre de $1946^{24}$ no hay mención al crimen de genocidio aunque sí a crímenes de lesa humanidad. Esto generó frustración en Lemkin y fue a la vez "uno de los motores para desarrollar una convención que defina al crimen de genocidio como un crimen que puede ser desarrollado en tiempos de guerra y en tiempos de paz, y que se separe de su limitación estricta de vinculación con la guerra" (Fernández, 2011: 35). Esto ya se había contemplado en la Ley del Consejo de Control $N^{\circ} 10.162$, promulgada por los Aliados en diciembre de 1945, que eliminó la conexión entre la guerra y los crímenes contra la humanidad y permitió el enjuiciamiento de los crímenes cometidos antes de 1939 contra civiles alemanes en una serie de juicios ante tribunales aliados y en los propios países ante tribunales internos. En ellos, ${ }^{25}$ como en la calificación del accionar de las Einsatz gruppen en Polonia y la Unión Soviética, se ratificó y se utilizó el concepto de genocidio ${ }^{26}$ (Schabas, 2009).

\section{De Nüremberg a la CONUG}

Tras los juicios, Lauterpacht y Lemkin continuaron sus campañas ${ }^{27}$ por una carta internacional de derechos humanos y un tratado para la prevención y el castigo del genocidio respectivamente. Estas iniciativas definirían fundamentalmente el nuevo orden jurídico internacional (Vrdoljak, 2009: 1194). Dos meses después del veredicto de Nüremberg, la Resolución 96 del 11 de diciembre de 1946, en el marco de la Primera sesión de la Asamblea General de la ONU, estableció que:

El genocidio es una negación del derecho de existencia de grupos humanos enteros, como el homicidio es la negación a los individuos del derecho a la vida; tal negación del derecho de existencia conmociona la conciencia de la humanidad, causa una gran pérdida en el aspecto cultural y otras contribuciones representadas por estos grupos humanos [...] Muchos ejemplos de tales crímenes de genocidio han ocurrido cuando grupos raciales, religiosos, políticos y de otro tipo han sido destruidos, por completo o en parte (Resolución 96, ONU). ${ }^{28}$

La resolución 96 además solicitó al Consejo Económico y Social (ECOSOC) que preparara un proyecto de convenio sobre el crimen de genocidio. Así, con la asistencia de la División de Derechos Humanos y de un grupo de tres expertos (Henri Donnedieu de Vabres, Raphael Lemkin y Vespasien Pella), preparó un proyecto borrador de convención acompañado de un comentario ${ }^{29} \mathrm{y}$ dos cuestiones que en la CONUG de 1948 desaparecerían: la protección a grupos políticos y el genocidio cultural ${ }^{30}$ que contemplaba cinco ítems: 
(a) transferencia forzada de niños a otro grupo humano;

(b) exilio forzado y sistemático de individuos que representan la cultura de un grupo;

(c) prohibición del uso de la lengua nacional incluso en relaciones privadas;

(d) destrucción sistemática de libros impresos en el idioma nacional o de obras religiosas o prohibición de nuevas publicaciones;

(e) destrucción sistemática de monumentos históricos o religiosos o su desvío a usos ajenos, destrucción o dispersión de documentos y objetos de valor histórico, artístico o religioso y de objetos utilizados en el culto religioso. ${ }^{31}$

En agosto de 1947, tras los comentarios al borrador de apenas siete estados, la Asamblea General pidió al ECOSOC que procediera a elaborar el texto definitivo sin esperar recibir las observaciones de todos los Estados Miembros. En marzo de 1948 el ECOSOC instituyó un Comité ad hoc sobre el genocidio, compuesto por representantes de China, Estados Unidos, Francia, Líbano, Polonia, la Unión de Repúblicas Socialistas Soviéticas y Venezuela, que tras veintiocho reuniones preparó un segundo proyecto de convención con comentarios. ${ }^{32}$

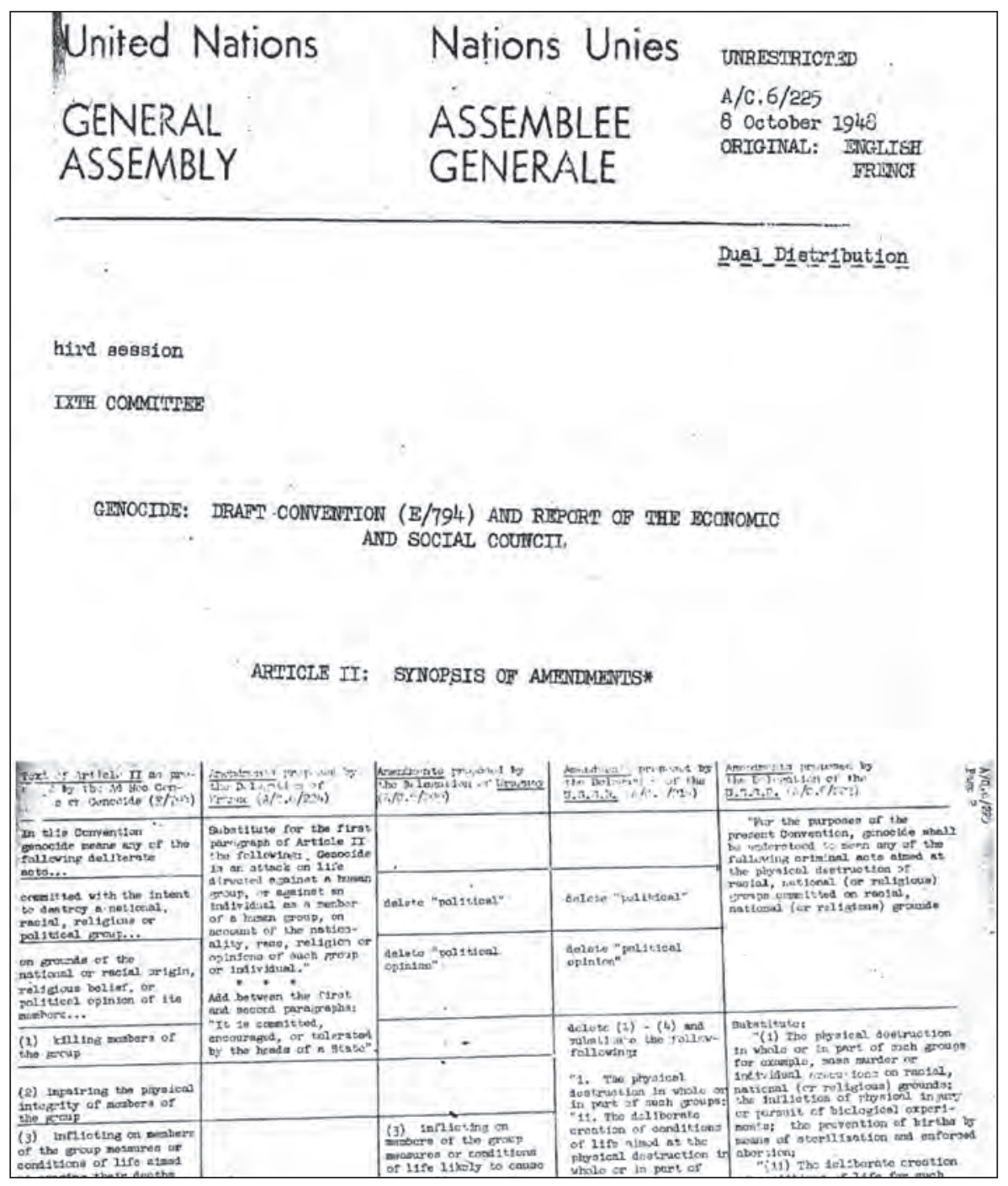

Figura 2. Síntesis de modificaciones del artículo 2 del proyecto de CONUG (E/794). En los recuadros puede verse la eliminación de grupos políticos.
31. Página electrónica de la ONU. Disponible en Internet: https://undocs.org/E/447. Consultado el: 21 de julio de 2018 .

32. ONU. E/794, $10 / 5 / 1948$. Disponible en Internet: https://undocs. org/E/794. Consultado el: 22 de julio de 2018. 
En el marco de la Tercera Asamblea General de Naciones Unidas, llevada a cabo entre septiembre y diciembre de 1948 en Francia, el borrador de la Convención fue derivado a la Sexta Comisión, órgano que examina los asuntos jurídicos y que a partir de un análisis artículo por artículo formuló cambios sustanciales: la inclusión en el artículo I de "ya sea que se haya cometido en tiempo de paz o en tiempos de guerra" que afirmaba la desconexión del crimen con la guerra; la eliminación del término "deliberado" antes de "actos"; la incorporación de que el genocidio no necesita de la eliminación total de un grupo sino que puede ser parcial; la redefinición de la noción de "grupos" protegidos, al añadir "étnicos" y eliminar "políticos"; el reemplazo de que el genocidio se cometió "por motivos del origen nacional o racial, creencia religiosa u opinión política de sus miembros con las enigmáticas palabras "como tal” (Schabas, 2009: 82, la traducción es nuestra), y la exclusión del genocidio cultural que repercutió en la cobertura periodística de la Asamblea.

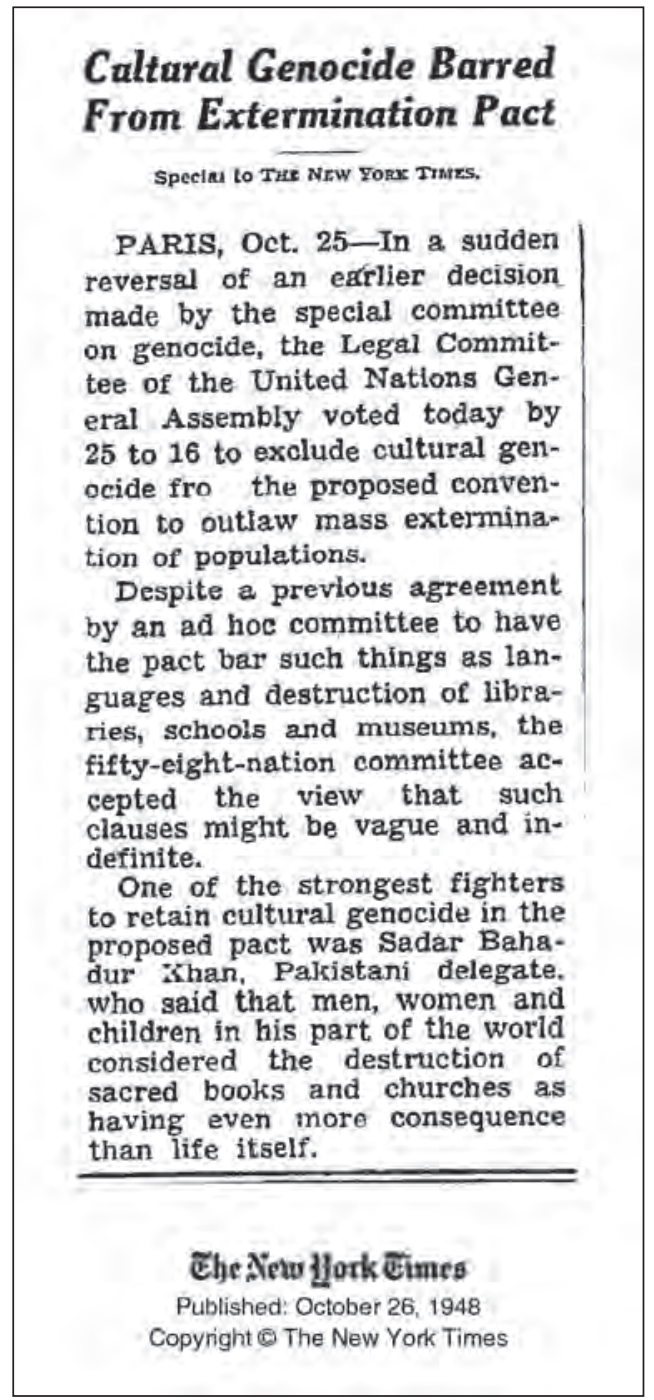

Figura 3. Genocidio cultural excluido del pacto de exterminio. The New York Times, 26/10/1948.

Algunas de las reformas generaron acaloradas discusiones, en especial la referida a los grupos protegidos que, a su vez, derivó en un deslizamiento inédito: que el genocidio sea el único crimen del derecho penal definido en calidad de la víctima y no por la práctica implementada. Daniel Feierstein afirma que: 
la firme oposición de la Unión Soviética y Gran Bretaña, junto a algunos de sus aliados como Polonia y Sudáfrica, a la correcta definición del delito llevó a una discusión sobre la inclusión o exclusión de diversos grupos (esto es la tipificación del delito por la víctima que lo sufre, algo inexistente hasta dicho momento en el derecho penal nacional o internacional) particularmente con la intención de excluir a "grupos políticos", "grupos económicos" o "grupos sociales" de la definición, en tanto se consideraba que podía implicar una intromisión a los derechos soberanos estatales [...] el representante francés, Donnedieu de Vabres se opuso fuertemente a la modificación, al considerar que la exclusión expresa de un grupo de personas podría interpretarse como "la legitimación de un crimen de esa clase que se perpetrara contra un grupo político" [...] y sostuvo que "mientras en el pasado los crímenes de genocidio se cometieron por motivos raciales o religiosos, es evidente que en el futuro se cometerían principalmente por motivos políticos" (Feierstein, 2009: 27-28).

En cambio, sí hubo consenso respecto a la base histórica del crimen de genocidio y el reconocimiento de que había existido mucho antes de la adopción de la Convención o de la Resolución 96 (Schabas, 2009), una idea que con el tiempo ha quedado invisibilizada por algunos académicos pese a que es parte del Preámbulo de la Convención: "Reconociendo que en todos los períodos de la historia el genocidio ha infligido grandes pérdidas a la humanidad" (CONUG, 1948). ${ }^{33}$
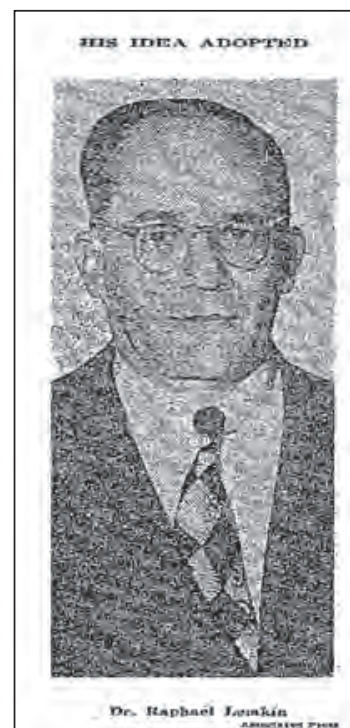

\section{U. N. VOTES ACCORD BANNING GENOCIDE}
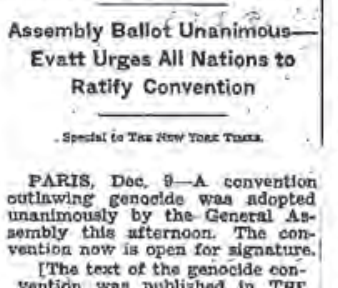

[The text of the ravioctale vention wan publiahed in THE
NEW York TIMES of Dec. 2.j The Soviet Dloe and Britain, Which abstainod when a final vote
was taken on the document in the Asgernbly's Legal Committes, swliched and voted in fayor today and ao abatentlons, South Africe, were ahaent when the ballot wes taken
After announcing the result of After announcing the result of
the roll call, Dr. Herbert $\mathrm{V}$. Evatt Assembly Preaident, urged that the convention be signed by all states Bnd ratifled by ail Parliaments at the earliest date. He told thi $A_{5}-1$
sembily that endeavors occusional preserve human groupg from de struetion through socalled humanitarian interventions undar-
tedten by one nation seting usually talen by one nation seting urtually
alone." Governmentis that undertooks such interventions were frequently ac cused of pursung other than "Today we are ostablishing in terriational collegtive aafegunrd for the very existence of such Whoever will act in the name of the United Nattotis will do it of behalt of unlversal conscience a embodied in this great organisa con Intervention of the tritio

other orgars which

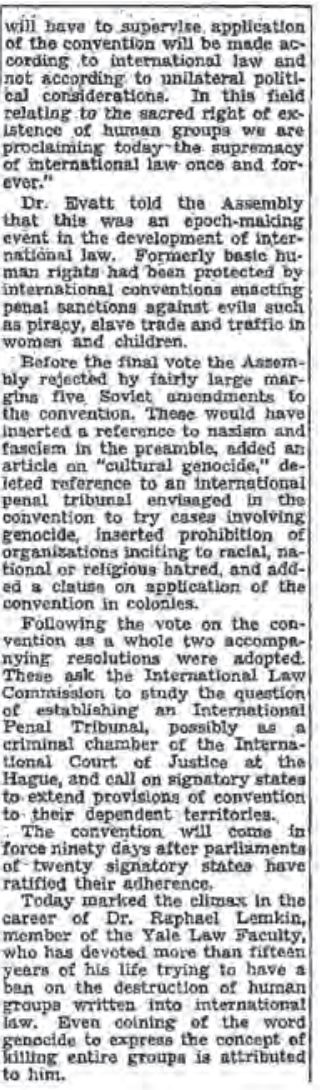

Che Xew Jjork Etunts

Publishod Desomitbor 10, 1048
33. CICR. Disponible en Internet: https://www.icrc.org/es/doc/ resources/documents/misc/treaty1948-conv-genocide-5tdm6h.htm. Consultado el: 20 de noviembre de 2017.

Figura 4. La ONU vota un acuerdo que prohíbe el genocidio. The New York Times, 10/12/1948. 
34. Un claro ejemplo es la Declaración Universal de Derechos Humanos, sancionada un día después de la CONUG, el 10 de diciembre de 1948 a través de la Resolución 217 A (III).

35. La CPI entró en vigor en 2002 y desde ese momento está abocada a juzgar crímenes de genocidio, de lesa humanidad y de guerra, en 2018 ha incorporado el crimen de agresión -iniciar una guerra. Entre sus limitaciones puede mencionarse que no posee policía y que tres de las cinco potencias del Consejo de Seguridad (China, Rusia y Estados Unidos) no han ratificado el Estatuto de Roma. Además suele recibir críticas por poner el foco casi exclusivamente en crímenes perpetrados en países africanos. Página electrónica de la Corte Penal Internacional. Disponible en Internet: www.icccpi.int. Consultado el: 20 de agosto de 2018.

36. Un señalamiento que ya en la década de 1950 había realizado Pieter Drost: "Una convención sobre genocidio no puede contribuir efectivamente a la protección de ciertas minorías cuando se limita a determinados grupos porque los miembros protegidos siempre pertenecen a al mismo tiempo a otros grupos desprotegidos" (Drost, 1959: 122, la traducción es nuestra).
El tema, sin embargo, fue parte de los debates cuando la Unión Soviética insistió por una enmienda que ligara el genocidio con el fascismo, el nazismo y las teorías de superioridad racial y Egipto respondió que se encontraban casos de genocidio en el pasado mucho más remoto, instancias que no tenían ninguna conexión en absoluto con teorías de superioridad racial (Hilberg, 2005: 1336; Schabas, 2009: 87).

También un texto largamente discutido respecto a la conformación de un tribunal o corte, basado en una noción de jurisdicción penal internacional, acompañó a la Convención que finalmente fue adoptada por 56 votos a favor y ninguno en contra, el 9 de diciembre de 1948.

\section{Nuevos contextos para discusiones pendientes}

La inmediata posguerra resultó un terreno fértil para el impulso del derecho internacional mediante pactos, tratados y convenios que desarrollaron el concepto de responsabilidad internacional por violación de derechos humanos. ${ }^{34}$ Sin embargo, las tensiones de la guerra fría congelaron la iniciativa de una Corte Penal Internacional (CPI), organismo que recién se concretaría en 1998, Estatuto de Roma mediante. ${ }^{35}$ Previamente, el Consejo de Seguridad de la ONU había creadolos Tribunales Penales Internacionales para la ex Yugoslavia (TPIY) y Ruanda (TPIR) en 1993 y 1994, respectivamente. Los tres en sus procesos y fallos se han expedido sobre genocidio y analizado y reinterpretado la CONUG (Fernández, 2011), que desde su sanción en 1948 fue motivo de discusión por su limitación de grupos víctima ${ }^{36}$ y por el requisito de intencionalidad (Bjornlund et al., 2005: 26):

El concepto de genocidio que se recepta en la convención es muy limitado, destinado a proteger a ciertos grupos y exige que haya una intención específica de destruir a esos grupos en todo o en parte. Es decir, se establece una figura muy acotada desde el punto de vista jurídico y cuyo juzgamiento también es acotado a principios de jurisdicción muy estrechos (Fernández, 2011: 36).

Como ha reconocido Schabas "la lista de grupos protegidos de la Convención probablemente haya provocado más debate desde 1948 que cualquier otro aspecto" (Schabas, 2009: 117, la traducción es nuestra), seguramente por lo que presagiaba Donnadieu de Vabres cuando se discutió la exclusión de los grupos políticos. Al respecto, Ward Churchill es claro al señalar que algunos estados habían querido "estrechar los parámetros definicionales de la Convención tanto como fuera necesario a fin de excluir muchas de sus pasadas, presentes y anticipadas políticas/prácticas" (Churchill, 1997, en Bjornlund, et al., 2005: 26).

Aun así, el desarrollo de los Tribunales Penales internacionales de Yugoslavia (TPIY) y Ruanda (TPIR) ha ampliado la perspectiva de la CONUG. En 1999 el TPIR declaró:

Los conceptos de grupos nacionales, étnicos, raciales y religiosos han sido analizados en profundidad y, en la actualidad, no existen definiciones precisas de los mismos aceptadas por la comunidad internacional. Cada uno de estos conceptos debe ser evaluado a la luz de un determinado contexto político, social y cultural. La sala advierte que a los fines de aplicar la CONUG, la pertenencia a un grupo es una noción subjetiva antes que objetiva. El perpetrador de genocidio percibe a la víctima como perteneciente a un grupo 
destinado a la destrucción (Fallo contra George Rutaganda. TPYR, 6/12/1999, en Bjornlund et al., 2005: 37).

En Argentina, el juzgamiento de los militares de la última dictadura (19761983) 37 también ha instalado el debate respecto a la noción de grupo víctima y la categorización -o no- del Proceso de Reorganización Nacional como un genocidio (Feierstein, 2007) que afectó a todo el grupo nacional:

[...] en el caso del genocidio, el grupo de víctimas no es verificado objetivamente -a partir de un dato constante de la realidad-, sino construido subjetivamente, merced a una operación intelectual. El grupo no preexiste "como tal", sino que es siempre construido por el represor, que traza un círculo sobre determinadas personas. El genocida construye al grupo (Ferreira, 2012: 93-94).

La convención sacó de la definición grupos políticos. Claro que el contexto histórico es fundamental. Pero esto que yo les he planteado, que en una convención finalmente se saque -por circunstancias coyunturales del momento, del mundo de aquella época- una frase o una palabra o un concepto, no significa que cuando hablemos de genocidio no estemos incluyendo a los perseguidos políticos. Ello porque sería completamente injusto para ese universo de víctimas [...] yo puse en una sentencia, que se da perfectamente a mi entender el requisito de "grupo nacional" en esa persecución que yo cuento que considero que hubo en Argentina [...] Y si bien jurídicamente yo entendía que no era posible condenar por genocidio, en cambio, era absolutamente imprescindible decir que esto había sucedido en el marco de un genocidio (Rozanski, 2011: 55-57).

Algunos de estos debates habían surgido en el seno de la ONU. En la década de 1970 el Consejo Económico y Social designó al ruandés Nicodème Ruhashyankiko como Relator Especial para desarrollar un estudio sobre la prevención y sanción del delito de genocidio, que fue presentado en 1978 con recomendaciones que hicieron hincapié en la creación de una corte o tribunal internacional. ${ }^{38}$ En 1983 el británico Benjamin Whitaker fue designado Relator Especial para la revisión y actualización de la CONUG. El informe, que lleva su apellido, fue presentado en $1985^{39}$ y significó un hito al reconocer al genocidio armenio, pese a las fuertes presiones del gobierno turco, ${ }^{40} \mathrm{y}$ por sus importantes aportes en la actualización de la categoría de genocidio.

Entre las novedades del informe figuran la confirmación de que el genocidio es un crimen con raigambre histórica, la inclusión de procesos anteriores a la CONUG como la masacre alemana de Hereros en 1904 o el genocidio armenio (punto 24), el reconocimiento de la falta de claridad de la CONUG acerca de cuáles son los grupos protegidos y una recomendación de ampliarlos (punto 30), el señalamiento -a partir del caso Camboyano- del "autogenocidio"; es decir, cuando las víctimas son parte del propio grupo de los perpetradores (punto 31), la posibilidad de ampliar la CONUG incorporando el genocidio cultural o etnocidio y el ecocidio (punto 32) y a los pueblos indígenas como grupos especialmente afectados por el genocidio. En esa línea el informe no solo apunta procesos del siglo XIX, como la colonización británica de Tasmania y el exterminio de los indígenas, sino que además menciona la masacre paraguaya de los indios ache antes de 1974 (punto 24) y refiere a África, Oceanía y las Américas como testigos de numerosos otros ejemplos de genocidio:

El genocidio, en particular en los pueblos indígenas, con frecuencia ha sucedido como consecuencia del colonialismo, el racismo y los prejuicios
37. Para un análisis detallado del debate en torno a la dictadura militar argentina (1976-1983) como práctica social genocida y los procesos de juzgamiento, ver Feierstein (2015).

38. ONU. E/CN.4/Sub.2/416: 184187. Disponible en Internet: https:// undocs.org/E/CN.4/Sub.2/416. Consultado el: 21 de julio de 2018 .

39. ONU. E/CN.4/Sub.2/1985/6. Disponible en Internet: https:// undocs.org/en/E/CN.4/Sub.2/1985/6 Consultado el: 21 de julio de 2018.

40. En versiones preliminares del informe Ruhashyankiko se mencionaba el genocidio armenio pero en esa ocasión las presiones turcas dieron resultado. Para un perfil de Benjamin Whitaker ver Clarín. “Un Británico que luchó por nosotros". Clarín. 2/7/2014, Sección Opinión. Disponible en Internet: https://www.clarin.com/opinion/ Whitaker-britanico-lucho_o_ Hkp3s05v7g.html. Consultado el: 20 de marzo de 2018. 
41. Informe Whitaker. Disponible en Internet: https://undocs.org/en/E/ CN.4/Sub.2/1985/6. Consultado el: 19 de Julio de 2018 .

42. Para un estado de la cuestión acerca de los estudios sobre genocidio ver Chalk y Jonassohn (2010).

43. Bauer expresaba: "Está claro que el Holocausto fue una forma de genocidio; No creo que haya que probar eso. Pero hay otros genocidios que ocurrieron en los últimos cien 0 doscientos años" (Bauer, 2010: 1, la traducción es nuestra). étnicos, siendo éstos comúnmente factores preponderantes. En algunos casos las fuerzas de ocupación mantuvieron su autoridad por el terror de la perpetua amenaza de una masacre (punto 21). ${ }^{41}$

Por un lado, el informe Whitaker se hacía eco de las respuestas a las consultas que el propio Relator le había realizado a los estados y, por otro, tomaba tópicos de los debates que se suscitaban en el incipiente, pero prolífico, campo de los estudios sobre genocidio. ${ }^{42}$ Para aquel entonces, Leo Kuper ya había delineado un modelo de cuatro genocidios que incluye el practicado contra pueblos aborígenes y que, en general, son perpetrados por estados o regímenes nuevos que intentan imponer el cumplimento de una nueva ideología (Kuper, 1985); Helen Fein había propuesto el genocidio por desarrollo, crimen que se produce cuando grupos colonizadores o de nuevos pobladores intentan destruir a los grupos nativos, ya sea por medio de la negociación, la lucha o la aniquilación dado que se interponen en el camino de la explotación económica de los recursos (Fein 1984, en Marco 2012). En su propuesta que actualizó tiempo después, Fein señaló a las personas -además de los estadoscomo potenciales genocidas y para ello tomó las matanzas de los pueblos indígenas en Paraguay y Brasil por parte de individuos colonizadores (Fein 1988, en Chalk y Jonassohn, 2010: 39-40). Unos años antes de la publicación del informe Whitaker, el historiador israelí Yehuda Bauer había presentado una distinción ${ }^{43}$ entre holocausto -reservado para el intento nazi de destrucción de los judíos de Europa- y genocidio en la que refiere, entre otros casos a "las tribus indígenas de Norteamérica víctimas de genocidio por razones de codicia y explotación, y su asesinato fue el resultado de políticas nacionales" (Bauer, 2016: 155):

El principal paralelismo es el sufrimiento de la víctima porque no hay diferencia absoluta entre los sufrimientos de los judíos, de los tutsis, de los camboyanos, de los armenios, de los indios estadounidenses, de cualquiera a lo largo de todo el curso de la historia. Ninguna diferencia. No hay mejor genocidio que otro genocidio (Bauer, 2010: 5).

Queda claro entonces que los estudios sobre genocidio partieron de la propia CONUG, sin dejar de criticarla y entenderla como una dilución de la propuesta de Lemkin y un concepto "esencialmente problemático" (Bjornlund et al., 2005: 21), y a partir de ello surge la recomendación de que las ciencias sociales se "emancipen" de la ley (Semelin, 2002, en Bjornlund et al., 2005: 18). Con todo, según la óptica de Bjornlund et al. (2005) parece existir un amplio consenso entre juristas y cientistas sociales de lo que podría considerarse la "esencia" del genocidio y es indudable que su origen como categoría en 1944 no fue sólo prevenir y sancionar el genocidio, sino también describirlo:

[...] la CONUG es un instrumento jurídico, pero también fue inspirada y guiada por un erudito que había estudiado el genocidio desde una perspectiva histórica y comparativa. Y tanto los aspectos jurídicos como los no jurídicos de la visión de Lemkin pueden hallarse en la CONUG (Bjornlund et al., 2005: 21).

En una reseña que escribió sobre el libro de Lemkin en la década de 1940, Lauterpacht fue muy crítico respecto al aporte jurídico de la noción de genocidio y sentenció que "no puede decirse precisamente que el volumen sea una contribución al derecho". Sin embargo reconoció que la obra era "imponente" y constituía "un erudito registro histórico" (Sands, 2017: 159). 
El señalamiento de la riqueza para el análisis histórico de la categoría de genocidio efectuada por Lauterpacht, responsable de introducir la noción de crimen de lesa humanidad en Nüremberg, en muchas ocasiones fue y es desdeñada por juristas y cientistas sociales. Este posicionamiento académico se emparenta con lo que Charny llamó "definicionismo", "una forma dañina de investigación intelectual basada en un compromiso fetichista y perverso con las definiciones hasta el punto en que se pierde la realidad del tema en discusión" (Charny, 1982, la traducción es nuestra).

El definicionismo da lugar a una interpretación muy estricta de la CONUG que virtualmente nunca se puede aplicar a casos reales (Schabas, 2009), además de otorgar el beneficio de la duda a los perpetradores y rechazar la historia de la redacción de la CONUG, cuando la propia historia indica que fue concebida con un significado amplio (Travis, 2017: 121).

Hasta hace poco tiempo en Argentina existía un área de vacancia con relación a los estudios sobre genocidios. Al mismo tiempo, su propia historia como estado nación moderno posee al menos dos etapas plausibles de ser debatidas como tales: la Conquista del Desierto y el Proceso de Reorganización Nacional. En la última década el campo ha crecido notablemente a partir de reflexionar e influenciar en los procesos jurídicos de Memoria, Verdad y Justicia vinculados a la última dictadura militar y, en menor medida, con la instalación del debate del genocidio de los pueblos originarios. ${ }^{44}$

En gran medida la publicación de clásicos traducidos al castellano ${ }^{45}$ como el de Lemkin ([1944] 2009) y Chalk y Jonassohn ([1990] 2010), entre otros, han alentado los debates y el interés por el tema. En esa línea, acceder en español a Historia y sociología del genocidio. Análisis y estudios de casos, aunque hayan transcurrido veinte años desde su publicación original, permite acercar a dos esferas con interrelaciones mínimas: los estudios sobre genocidio y las investigaciones sobre pueblos indígenas. ${ }^{46}$ La posibilidad de acceder al estudio de veintidós procesos genocidas, de los cuales catorce son previos a la CONUG y muchos referidos a pueblos indígenas desde la Conquista de América, pasando por la expansión de los Estados Unidos en el siglo XIX a costa de distintas comunidades originarias hasta la matanza de indígenas en el Amazonas durante el siglo $\mathrm{XX}$, ayuda de gran manera, en las propias palabras de sus autores, a "demostrar que el genocidio ha ocurrido a lo largo de toda la historia y en todas partes del mundo" (Chalk y Jonassohn, 2010: 89).

\section{Algunas notas sobre la relación entre la categoría de genocidio y su aplicabilidad al sometimiento de la población originaria en Argentina}

En este apartado relacionamos algunas cuestiones que fueron abordadas en los puntos anteriores pero enfocadas al proceso de sometimiento de la población originaria en Argentina a fines del siglo XIX. A modo de síntesis, referimos al asesinato, apresamiento, traslados, confinamientos en campos de concentración, cambios de nombre, bautismos, distribución de la población separando las comunidades y familias, etc. (Nagy, 2015).

Entendemos a este proceso como genocidio (Roulet y Garrido, 2011; Lenton, 2014; Delrio et al., 2018), como una práctica social genocida (Feierstein, 2007) que construye un otro negativo y cristaliza una realización simbólica de los acontecimientos, dominada por un relato hegemónico que encuadra los
44. Ver Sección Debate, revista Corpus 1 (2), 2011. Disponible en Internet: http://ppct.caicyt.gov.ar/ index.php/corpus/article/view/740 y el dossier Genocidio y Pueblos Originarios publicado en Revista de Estudios sobre Genocidio 13, 2018. Disponible en Internet: http://www. revistasuntref.com.ar/index.php/ reg.

45. El proyecto "Estudios sobre Genocidio" es fruto de un acuerdo conjunto entre la editorial Prometeo y la Universidad de Tres de Febrero y contó con el apoyo del Programa de las Naciones Unidas para el Desarrollo (PNUD).

46. Con la excepción de los trabajos de la Red de Investigadores en Genocidio y Política indígena en Argentina (RIGPI). 
47. Con deslizamientos negacionistas referimos a una serie de aseveraciones que en el afán de discutir la idea de genocidio terminan negando y deformando la caracterización del proceso histórico.

48. Código Lieber. Disponible en Internet: https://ihl-databases.icrc. org/ihl/INTRO/110. Consultado el: 26 de enero de 2018.

49. Ver página electrónica de la Cruz Roja Argentina. Disponible en Internet: http://cruzroja.org. ar/?page_id=1107. Consultado el: 20 de marzo de 2018. acontecimientos y al status quo como naturales y al indígena como un actor social del pasado que debía extinguirse al calor del progreso civilizatorio.

La noción de la Conquista del Desierto como genocidio recibe ciertas críticas que podrían caracterizarse como deslizamientos hacia el negacionismo: ${ }^{47} \mathrm{el}$ anacronismo, la guerra, la agencia indígena y la militancia.

El supuesto anacronismo del concepto de genocidio para juzgar prácticas del siglo XIX, pese al mencionado preámbulo de la propia CONUG que afirma su historicidad, es sostenido no solo por discursos mediáticos sino también por especialistas. Roulet y Garrido afirman que:

la consagración jurídica de los conceptos que designan prácticas delictivas siempre es posterior a la generalización de su uso, ya que el delito precede al concepto y éste precede al tipo penal. Lo reciente del término genocidio no debe hacernos olvidar que se trata de un nuevo nombre para un crimen tan viejo como el mundo (Roulet y Garrido, 2011: 5).

Como hemos explicado, y las propias autoras sostienen, en la segunda mitad del siglo XIX se impuso "una dinámica tendiente a humanizar los usos bélicos" (Roulet y Garrido, 2011: 5) que incluyó, en 1863, el origen de la Cruz Roja y el Código Lieber en Estados Unidos. En su extensa codificación, si bien protegía a los prisioneros de guerra, el Código Lieber también reserva un artículo a los denominados pueblos bárbaros:

La regla casi universal en los tiempos remotos fue, y sigue siendo así con los ejércitos bárbaros, que el individuo del país hostil está destinado a sufrir cada privación de libertad y protección, y cada interrupción de los lazos familiares. La protección era, y todavía lo es para las personas incivilizadas, la excepción (Código Lieber, art. 24). ${ }^{48}$

Este aspecto no es menor por dos motivos. Primero porque Julio Roca estudió la política estadounidense aplicada con los pueblos indígenas (Nagy, 2015) por tanto no podía desconocer el Código Lieber ni las leyes de la guerra y, en especial, porque en 1879, cuando se inició la Conquista del Desierto, el gobierno argentino presidido por Nicolás Avellaneda ratificó el Primer Convenio de Ginebra y un año después, en 1880, en nuestro país se fundó la Cruz Roja. ${ }^{49}$ Por tanto, el artículo 24 del Código Lieber fue el artilugio para eludir los compromisos asumidos en el plano internacional mediante, lo que Roulet y Navarro Floria han denominado como la "domesticación o internalización de la cuestión indígena" (2005: 25), en términos de una guerra interna entre civilización y barbarie; esto es un proceso de transferencia gradual de las relaciones con las naciones indígenas del ámbito del derecho internacional al de la legislación interna:

En un largo proceso de elaboración discursiva que tenía como finalidad la afirmación de soberanía estatal sobre territorios y pueblos hasta entonces pertinazmente externos a las repúblicas en gestación fue cobrando forma un mito que echaría honda raíz en el imaginario colectivo. Según él, las naciones originarias soberanas con quienes los Estados coloniales y republicanos habían firmado tratados de paz hasta la década de 1870, no constituían sino hordas de salvajes morando en desiertos más allá de una "frontera interior" que amputaba al país una parte sustancial de los territorios que por derecho le pertenecían (Roulet y Garrido, 2011: 3). 
Queda claro que el estado argentino conocía las limitaciones impuestas por distintos códigos y regulaciones a las que debía atenerse al momento de realizar la Conquista del Desierto a fines de la década de $1870^{50}$ y operó en la construcción de un otro negativo (Feierstein, 2007) para legitimar el sometimiento indígena. Las políticas implementadas con la población originaria se ajustan a la definición y la descripción de genocidio que acuñara Lemkin y consagrara la CONUG (Lenton, 2010).

Si bien no es un posicionamiento novedoso, la idea de reemplazar genocidio por guerra, más allá de sus adjetivaciones, también ha permeado el debate en torno a los pueblos indígenas en Argentina. Tal operación fue incluida por Gregory Stanton (2004) quien expresa: “al retratar la situación como guerra civil en lugar de genocidio, los negadores apelan al malentendido de que los dos son mutuamente excluyentes". ${ }^{51}$ Como vimos, el origen de los crímenes internacionales y su juzgamiento están ligados a la guerra y recién con el tiempo se dio lo que los especialistas llaman "el declive de la conexión" (Vives Chillida, 2003: 50). Por tanto, en principio, de ningún modo puede referirse a la guerra y al genocidio como excluyentes en función de que, por el contrario, su interpretación original era que uno -el genocidio- ocurría en el transcurso del otro -la guerra-. En segundo término, si pensamos en el nazismo como genocidio "modelo", no existe ningún trabajo que proponga no comprenderlo como genocidio porque habría que catalogarlo como guerra relámpago. Son aspectos distintos por ello, aunque suscribiéramos a la noción de guerra adjetivada como "social" (Vezub et al., 2015) para explicar la Conquista del Desierto, queda claro que no abarca las políticas estatales en su totalidad. En tercer término, afirmar que el sometimiento indígena, la separación de las familias, su deportación y confinamiento en campos de concentración, el borramiento de identidades y su distribución fue una guerra se acerca a un deslizamiento negacionista que no es inocente políticamente, dado que en nuestro país los negacionistas del terrorismo de estado llevado a cabo por la última dictadura militar, justamente apelan a que se trató de una guerra adjetivándola como guerra "sucia". ${ }^{52}$

Finalmente, en el caso particular de la Conquista del Desierto, la idea de guerra, alguna vez utilizada por las plumas militaristas (Walther, [1948] 1970), pareciera reaparecer en la actualidad más como categoría editorial; es decir, producto de una oportunidad de publicar y no tanto como fruto de la reflexión académica. ${ }^{53} \mathrm{Tal}$ vez por ello algunas aseveraciones críticas, como la de "discutir con la visión de una maquinaria estatal que avanza" luego es sustentada con una noción de guerra "como maquinaria de construcción social y política" o "una maquinaria de construcción (y destrucción) sociopolítica sin igual" (Vezub et al., 2015: 225-226).

Por todo esto, coincidimos con Travis quien sostiene que "los investigadores y otros escritores han hecho brillar sistemáticamente la luz de la verdad sobre los intentos de ocultar el genocidio en la niebla de la guerra" (Travis, 2017: 104).

El tercero de los deslizamientos es el que asegura que si hablamos de genocidio se obtura la agencia ${ }^{54}$ indígena dado que este concepto operaría como un manto que negaría el accionar, la diplomacia y las modalidades de hacer política de los pueblos originarios. Esta presunción nos haría pensar que si dijéramos -nuevamente- que el nazismo perpetró un genocidio, obturaríamos la agencia de las víctimas; entonces, por ejemplo, no se podría hacer mención a la rebelión del gueto de Varsovia. La noción de agencia que esta hipótesis intenta sustentar es restringida, acotada al momento de las campañas militares.
50. En esa línea, Taner Akcam afirma que el imperio otomano se había convertido en miembro de "la familia de Europa" y aceptado las cargas y obligaciones de la ley internacional al firmar el Tratado de Paris de 1856 (Akcam, 2010: 303).

51. En 1996, Stanton había propuesto ocho modalidades, luego agregaría la discriminación y la persecución. Disponible en Internet:-http:// www.genocidewatch.org/genocide/ tenstagesofgenocide.html. Consultado el: 10 de abril de 2018 .

52. Es cierto que Inés Izaguirre (2009), desde un enfoque ideológico de izquierda, describe la etapa 1973-1983 como guerra civil, pero al mismo tiempo entiende al Proceso de Reorganización Nacional como un genocidio.

53. Puede constatarse que el capítulo mencionado de Vezub et al. (2015) se inscribe en un libro sobre las guerras argentinas -ver bibliografíay que, en 2013, uno de sus autores había incursionado en la categoría de proceso de popularización indígena en el marco de una compilación sobre participación popular en el siglo XIX. Ver Di Meglio y Fradkin (2013).

54. La idea de agencia tensiona con la de estructura y se relaciona con las posibilidades de acción e intervención de los sujetos en los procesos de transformación de la realidad. Puede definirse como los modos en que los sujetos indígenas participan en la contienda política, permite revelar las bases ideológicas de dicha contienda y también cómo la participación de diferentes sujetos y grupos las reproduce o las transforma (Ortner, 2016). 
55. Klarsfeld nació en Berlín en 1939 y fue galardonada en 1984 con la Legión de Honor, junto con su marido Sergio Klarsfeld, por haber dedicado su vida a localizar, perseguir y llevar ante la justicia a criminales nazis. Dirige una fundación que lleva su nombre y persigue a criminales de lesa humanidad.
Resalta el ethos guerrero (ver Delrio et al., 2018) de los lanceros del siglo XIX y rescata como única fuente valedera la voz de los caciques pero desconoce el proceso de emergencia y movilización política ocurrido desde la recuperación democrática de 1983 (Briones, 2005), que habilitó la denuncia de distintas comunidades indígenas y su caracterización de la conquista como genocidio. En esta interpretación la agencia sólo se halla en el pasado y es negada en el presente. De este modo, ¿sería aceptable pensar que la única voz permitida sobre la dictadura militar (1976-1983) fueran las cartas escritas en aquel entonces por dirigentes de organizaciones revolucionarias y no se contemplaran las memorias y los posicionamientos de los sobrevivientes, sus hijos y sus nietos desarrollados en la posdictadura?

La última cuestión es la esencia militante del concepto de genocidio. Dicha consideración se contrapondría a una labor académica neutral y objetiva sin involucramientos en el campo de estudio. Como se expuso, no hay dudas de que la categoría de genocidio, la CONUG y su instalación pública es en gran parte obra de la tenaz militancia de Raphael Lemkin. En Argentina, su utilización académica fue producto de la movilización indígena por el reconocimiento, la ampliación de derechos y la militancia en hitos como los contra-festejos por el V Centenario de 1992 o la reforma constitucional de 1994.

Como han demostrado otros casos históricos ya mencionados, los procesos de Memoria, Verdad y Justicia han podido avanzar no solo por la reflexión teórica y académica sino también, y de manera imprescindible, por la movilización de distintos actores de la sociedad, incluidos los investigadores. Esa militancia, en palabras de Beate Klarsfeld ${ }^{55}$ reconocida mundialmente por dedicar su vida a perseguir nazis, ha posibilitado que "por primera vez en la historia de la humanidad, se sigue juzgando a hombres por crímenes que cometieron hace casi setenta años. A un crimen excepcional responde un esfuerzo excepcional" (Klarsfeld, 2011).

Entendemos que como académicos, el caso particular de los pueblos indígenas en Argentina, en especial con las políticas estatales y sus consecuencias a partir de la Conquista del Desierto, nos obliga no solo a documentar y fundamentar con rigor las prácticas genocidas y dar cuenta de los deslizamientos hacia el negacionismo, sino también a honrar a sus víctimas a partir de un posicionamiento ideológico que pueda aportar no a la pretensión paternalista de "dar voz a los que no tienen voz", sino a escribir una historia nacional crítica del racismo, los prejuicios y respetuosa de las comunidades originarias y la diversidad cultural.

Con esa intención nació este artículo y este dossier.

\section{Recapitulación}

El crimen que Lemkin definió como genocidio en 1944 es de larga data. Su inclusión como un delito del derecho internacional fue producto de arduas discusiones e intensas acciones de militancia que no pueden escindirse de los contextos políticos e históricos en los que se produjeron. Al estudio de Lemkin, destacado por su intención de sancionar y prevenir el genocidio, en ocasiones no se le reconoce su riqueza descriptiva y analítica.

Este artículo intentó reponer los sinuosos caminos históricos y sus debates hasta la sanción de la CONUG, los planteos posteriores, los intentos de 
ampliación y actualización de la Convención y la interrelación entre ciencias sociales y jurídicas en la comprensión del concepto y sus alcances en el presente. Como hemos visto los tópicos más polémicos son la exclusión de los grupos políticos, la eliminación del genocidio cultural y la dificultad de demostrar la intencionalidad genocida en los juicios ${ }^{56}$ (Fernández, 2011).

Finalmente hemos avanzado en la descripción de lo que entendemos como deslizamientos negacionistas en la interpretación de las campañas militares de sometimiento de la población originaria en Argentina.

En tal sentido, el repaso y el análisis de la historia del concepto de genocidio y sus derroteros nos parece fundamental para la comprensión del proceso histórico de construcción del estado nación argentino y sus políticas con las comunidades indígenas.
56. En vista de las dificultades para demostrar la "intencionalidad" de un genocidio en un juicio y del reforzamiento del concepto de lesa humanidad, delito que acarrea las mismas sanciones, en el campo jurídico es común que se opte por crimen de lesa humanidad. Sin embargo en Argentina, en los últimos años se ha incrementado la cantidad de causas que hacen alusión al genocidio. A diciembre de 2014 se contabilizan 134 sentencias en todo el país de las cuales 102 califican los hechos como delitos de lesa humanidad y 32 como genocidio. Con todo, el $40 \%$ de las causas que no reconocen la existencia de genocidio lo debaten en sus fallos. A su vez, de las que consideran genocidio, un tercio lo reconoce sólo en términos histórico-sociales sin extender el concepto a su calificación jurídica (Silveyra, 2016: 240). 


\section{Fuentes citadas}

» Diario Le Monde (Francia)

»Diario The New York Times (Estados Unidos))

»Diario The Washington Post (Estados Unidos)

»Documentos oficiales de la Organización de Naciones Unidas (ONU).

»Página electrónica del Comité Internacional de la Cruz Roja (ICRC)

"Página electrónica de la Cruz Roja (Argentina)

»Página electrónica de la Corte Internacional de Justicia

»Página electrónica de la Corte Penal Internacional

»Página electrónica de Prevent Genocide International 


\section{Q Bibliografía citada}

" Akcam, T. (2010). Un acto vergonzoso: el genocidio Armenio y la cuestión de la responsabilidad turca. Buenos Aires, Colihue.

»Artinian, J. y A. Papazian (2013). El genocidio armenio: Educación en Derechos humanos. Buenos Aires, Fundación Luisa Hairabedian.

» Bauer, Y.(2010). Lectura de Yehuda Bauer.3 de Noviembre. Disponible en Internet:http:// www.holocaustremembrance.com/sites/default/files/transcription_bauer_lecture.pdf. Consultado el: 12 de junio de 2018.

" Bauer, Y. (2016). El holocausto y las comparaciones con otros genocidios. Revista Mexicana de Ciencias Políticas y Sociales 228: 145-172.

" Bautista Jiménez, J. M. (2008). La vinculación entre la protección de algunos derechos fundamentales y la "seguridad y paz" internacionales: el antecedente de la sociedad de naciones. Revista electrónica de estudios internacionales 16:1-37.

"Bjornlund, M.; Markusen E. y M. Mennecke (2005). “¿Qué es un genocidio?” en Feierstein, D. (comp.), Genocidio, la administración de la muerte en la modernidad: 17-48. Buenos Aires, Editorial de la Universidad Nacional de Tres de Febrero.

》 Briones C. (2005). “Formaciones de alteridad: Contextos globales, procesos nacionales y provinciales" en Briones, C. (coord.), Cartografías argentinas: políticas indígenas y formaciones provinciales de alteridad: 11-44. Buenos Aires, Antropofagia.

"Chalk, F. y K. Jonassohn ([1990] 2010). Historia y Sociología Del Genocidio: Análisis y estudio de Casos. Buenos Aires, Prometeo.

" Charny, I. (1982). How Can We Commit the Unthinkable? Genocide: The Human Cancer. Boulder, Westview Press.

》 Delrio, W.; Escolar, D.; Lenton, D. y M. Malvestitti (dirs.) (2018). En el país de nomeacuerdo. Archivos y memorias del genocidio del Estado argentino sobre los pueblos originarios, 18701950.Río Negro, Editorial de la Universidad Nacional de Río Negro.

"Di Meglio, G. y R. Fradkin (comps.) (2013). Hacer política. La participación popular en el siglo XIX rioplatense. Buenos Aires, Prometeo.

》Drost, P. (1959). The Crime of State, Vol. 2, Genocide. Leyden, Sijthoff.

»Elliott, J. (1999). Europa después de la paz de Westfalia. Pedralbes 19: 131-146.

» Feierstein, D. (2007). El genocidio como práctica social. Buenos Aires, Fondo de Cultura Económica.

» Feierstein, D. (2009). "Estudio preliminar” en Lemkin, R., El dominio del Eje en la Europa ocupada: 23-38. Buenos Aires, Prometeo.

» Feierstein, D. (2015). Juicios. Sobre la elaboración del genocidio II. Buenos Aires, Fondo de Cultura Económica.

"Fernández, S. (2011). "Juzgar los crímenes de genocidio: de Nüremberg a La Haya" en Perel, R. (coord), La Shoá, los genocidios y crímenes de lesa humanidad: Enseñanzas para los juristas: 32-40. Buenos Aires, Secretaría de Derechos Humanos.

"Ferreira, M. (2012). El genocidio y su caracterización como "eliminación parcial de grupo nacional". Derecho Penal y Criminología 8: 84-99.

" Galán Martín, A. (2015). “La paz de Westfalia (1648) y el nuevo orden internacional”. 
Facultad de Filosofía y Letras, Universidad de Extremadura. Disponible en Internet: http://dehesa.unex.es/bitstream/handle/10662/3319/TFGUEX_2015_Galan_Martin. pdf? sequence $=1$. Consultado el: 24 de junio de 2018 .

» Gerd, H. (2014). The Leipzig trials. German war crimes and their legal consequences after World War I. Dordrecht, Republic of Letters Publishing.

» Hilberg, R. (2005). La destrucción de los judíos europeos. Akal, España.

» Izaguirre, I. (dir.) (2009). Lucha de clases, guerra civil y genocidio en Argentina 1973-1983: antecedentes, desarrollo, complicidades. Buenos Aires, Editorial Universitaria de Buenos Aires.

» Klarsfeld, B. (2011). “El combate por la justicia y la memoria” en Perel, R. (coord.), La Shoá, los genocidios y crímenes de lesa humanidad: Enseñanzas para los juristas: 18-29. Buenos Aires, Secretaría de Derechos Humanos.

» Kuper, L. (1985). The Prevention of Genocide. New Haven, Yale University Press.

»Lemkin, R. ([1944] 2009). El dominio del Eje en la Europa ocupada. Buenos Aires, Prometeo.

» Lemkin, R. (1947). Genocide. The American Scholar 15: 227-229.

»Lenton, D. (2010). “La 'cuestión de los indios’ y el genocidio en los tiempos de Roca: sus repercusiones en la prensa y la política” en Bayer, O. (coord.), Historia de la crueldad argentina. Julio A. Roca y el genocidio de los Pueblos Originarios: 29-50. Buenos Aires, El Tugurio.

»Lenton D. (2014). “Apuntes en torno a la aplicabilidad del concepto de genocidio en la historia de las relaciones entre el estado argentino y los pueblos originarios” en Lanata, J. L. (comp.), Prácticas Genocidas y Violencia Estatal en Perspectiva Transdisciplinar: 32-51. San Carlos de Bariloche, IIDyPCa-CONICET.

» Marco, J. (2012). “Genocidio y Genocide Studies : Definiciones y debates”. Hispania Nova 10: 336-377.

» Nagy, M. (2015). Pueblos indígenas y estado. Aportes para una reflexión crítica en el aula. Buenos Aires, Ministerio de Educación de la Nación argentina.

» Nora, P. (1984). Los lugares de la memoria. Madrid, Trilce.

» Ortner, S. (2016). Antropología y teoría social: Cultura, poder y agencia. Buenos Aires, Universidad Nacional de Gral. San Martín.

» Roulet, F. y M. Garrido (2011). El genocidio en la historia: ¿Un anacronismo? Corpus. Archivos virtuales de la alteridad americana 1(2): 1-9. Disponible en Internet: http://ppct. caicyt.gov.ar/index.php/corpus/article/view/744/653. Consultada el: 28 de mayo de 2018.

» Roulet, F. y P. Navarro Floria (2005). De soberanos externos a rebeldes internos: la domesticación discursiva y legal de la cuestión indígena en el tránsito del siglo XVIII al XX. Tefros 3 (1): 1-41.

» Rozanski, C. (2011). “¿Para qué juzgar?” en Perel, R. (coord), La Shoá, los genocidios y crímenes de lesa humanidad: 50-57. Enseñanzas para los juristas. Buenos Aires, Secretaría de Derechos Humanos.

"Sands, P. (2017). Calle Este-Oeste. Sobre los orígenes de "genocidio" y "crímenes contra la humanidad". Barcelona, Editorial Anagrama.

» Schabas, W. (2009). Genocide in international law. The Crimes of crimes. Cambridge, Cambridge University Press.

» Silveyra, M. (2016). “Los tribunales cuentan la historia. Los aportes de las sentencias 
judiciales en los sentidos y relatos del genocidio argentino" en Levy, G. (coord.), De militares y empresarios a políticos y Ceos: reflexiones a 40 años del golpe: 237-258. Buenos Aires, Gorla.

»Stanton, G. (2004). The 10 Ways to Deny Genocide. Disponible en Internet: http://www. genocidewatch.org/genocide/tenstagesofgenocide.html. Consultado el: 10 de abril de 2018.

» Travis, H. (2017). Sobre la comprensión originaria del crimen de genocidio. Revista de Estudios sobre Genocidio 12: 101-128.

»Vezub, J.; Salomón Tarquini C. y D. Escolar (2015). “La Campaña del Desierto (18701890): notas para una crítica historiográfica” en Lorenz, F. (comps.), Historia de la guerra en la Argentina: 223-247. Buenos Aires, Ariel.

»Vives Chillida, J. (2003). La evolución jurídica internacional de los crímenes contra la humanidad. Cursos de Derecho Internacional y Relaciones Internacionales de Vitoria-Gasteiz/Vitoria-GasteizkoNazioartekoZuzenbide eta NazioartekoHarremanenlkastaroak: 329-383. Disponible en Internet: https://www.ehu. eus/documents/10067636/10679022/2003-Julio-Vives-Chillida.pdf/2ebccaa6-f443-433e9as6-68232b59od2a. Consultado el: 10 de abril de 2018.

"Vrdoljak, A. (2009). Human Rights and Genocide: The Work of Lauterpacht and Lemkin in Modern International Law. The European Journal of International Law 20 (4): 1163-1194.

»Walther, J. ([1948]1970). La conquista del desierto. Síntesis histórica de los principales sucesos ocurridos y operaciones militares realizadas en La Pampa y Patagonia, contra los indios (años 1527-1885). Buenos Aires, Editorial Universitaria de Buenos Aires. 